\title{
Priority Spatial use for Sustainable Residential Area Around Limboto Lake Area (Case Study: Kayubulan Village)
}

\author{
Ertina Ginting ${ }^{1}$, Ragil Haryanto ${ }^{2}$ \\ \{ertina.bdg@gmail.com ${ }^{1}$, ragil.haryanto@pwk.undip.ac.id ${ }^{2}$ \} \\ ${ }^{1}$ Public Works Agency, Gorontalo, Indonesia \\ ${ }^{2}$ Diponegoro University, Semarang, Indonesia
}

\begin{abstract}
Development of residential areas in Limboto district urban area encourage spatial use around Limboto Lake, which one is Kayubulan village. The rapid development of residential area has led to spatial use chnges in Kayubulan village, where the number of built spaces has increased and it has urged protection functions become residential areas. It is feared that spatial use for residential can affect the area around Limboto Lake which has limitations in spatial use. This study aims to examine the priority of spatial use for sustainable residential area around Limboto Lake especially in Kayubulan village based on the potential and limitations by considering the perceptions and priorities of respondents. Respondents in this study consisted of elements that government, universities, private/associations and fishing communities. This study using combined method (mix-used method) with the Analytic Hierarchy Process (AHP) analysis tool. The results showed that priority for residentials area in Kayubulan village is the limited use of space for conditional sustainable residentials. The priority criteria for spatial use of sustainable residential area that must considered the environment and disaster with a weight of $48 \%$ and the priority of sub-criterion that the residential is outside the flood disaster area with a weight of $17.02 \%$. Limited of spatial use for conditional sustainable residential carried out by considering aspects of layout, environmental aspects and disaster aspects that refer to the provisions, regulations, and applicable provisions.
\end{abstract}

Keywords: Spatial Use, Sustainable Residential Area, Limboto Lake, Analytic Hierarchy Process (AHP).

\section{Introduction}

Human activities require space as the location of various activities, which one is residential location. Residential is one of the basic human needs and living environment that more than just a house or housing containing the integration of the interests and harmony utilization as life environment(Sadana, 2014). Population growth and increased economic activity in the region requires a new space, especially in urban areas. Muta'ali (2013) argued that population growth will have an impact on the increased need for land for residentials.

Land use development represents a growing human needs, especially the primary needs to build a house (Widodo et al., 2015). In addition to impact on land requirement, and population growth can also result in an increased need for space while the increased need for space trigger growth and development of urban areas(Daldjoeni, 1996).This may create new problems 
because availability of land is getting less and space that can be used as a residential area is limited while the number of people continues to increase.

Increased residential land needs to have an impact on land use changes rapidly from the protected area becomes ultimately the cultivated area tends to violate the layout. One was the use of space protected area lakes into cultivated area. Land use changes around the lake occurs due to various factors. As disclosed Connell and Millner (1995), that to satisfy human interests, the environment around the lake changed to conform to the way of lifeand reside human being, or even the area around the lake is often overhauled to accommodate the various forms of human activity such as housing, roads, drains household waste, farmland, recreation and so on. Act of number 26 Year 2007 on Spatial Planning explained that the lake and borders, includes that protected area function which bans activities and activitity area on the land as residential activity.

One of the significant impacts caused by the conversion of land into building are environmental problems (Sulistiono, 2006; Widodo, 2004) such as floods, droughts, groundwater contamination, environmental illness, waste, increased local temperature, and others. The quality of life in the form of comfort and safety of a dwelling house determined by its location (Luhst, 1997). Residential area should be built in locations distant from disasters. Act of number 26 Year 2007 on Spatial Planning insists that preparation of spatial planning, especially for residential areas should pay attention and avoid disaster-prone areas. The reality on the ground shows that humans can not always build residentials far from the source of disaster (Sadana, 2014) due to certain factors, such as economic factors,

Many development activities have resulted in poverty, deterioration and damage to the environment (Mitchell et al., 2003), one of which is due to residential construction. Therefore, residential development planning must consider aspects of environmental protection as an act of responsibility and the ethics of the environment(Widodo et al., 2015), It is to achieve a sustainable residential. The essence of sustainable residential development is an effort to improve the quality of life in a sustainable manner (Kirmanto 2002).

From that explanation above, this study aims to assess the priority direction of spatial use for a sustainable residential around of Lake Limboto, especially Kayubulan village as case studies. This study discuss present the spatial use directives for sustainable residential taking into account the potential and limitations, and recommend mitigating floods in the research area.

\section{Location Study}

The study location is Kayubulan village, which Kayubulan village located ini are in Limboto district, Gorontalo Regency. This area has an area of $4.8 \mathrm{~km}^{2}$ or $480 \mathrm{Ha}$ and Limboto directly borders to the lake. Kayubulan administratively adjacent in the North side with Kayumerah village; South side bordered by Limboto Like; East side bordered by Hepuhulawa village; West side bordered by Hunggaluwa village.

Limboto Lake as largest lake on Gorontalo Province which one of the 'landmark' ecosystem. Gorontalo Province that serves as a conservation and flood control are now in a critical condition. Based Data Centers Sulawesi River Region II (2014), that an area of $54 \mathrm{~km}^{2}$ territory Limboto watershed forest has been turned into farmland and residentials during the past 10 years. Shallowing of the lake led to the emergence of land, either in the middle or on the edge of the lake. This land has been used by residents to farmland (637 ha of rice fields, fields 329 ha), residential (1,272 ha), and other uses (3,594 ha) as well as most of the land has 
become proprietaryRegional Spatial Plan (RTRW) Gorontalo Regency Year 2012-2032, this area designated as a residential area along Limboto Lake and flood prone areas. The problems that occurs in this area that residential development that utilizes a protected area that is space agency Limboto lake and borders. One of the spatial usefor residentials in Limboto Lake ass a special housing construction fisherman Lake Limboto by the Ministry of Public Works and Public Housing in 2016. Overview study areas indicated on Figure 1 and Figure 2.

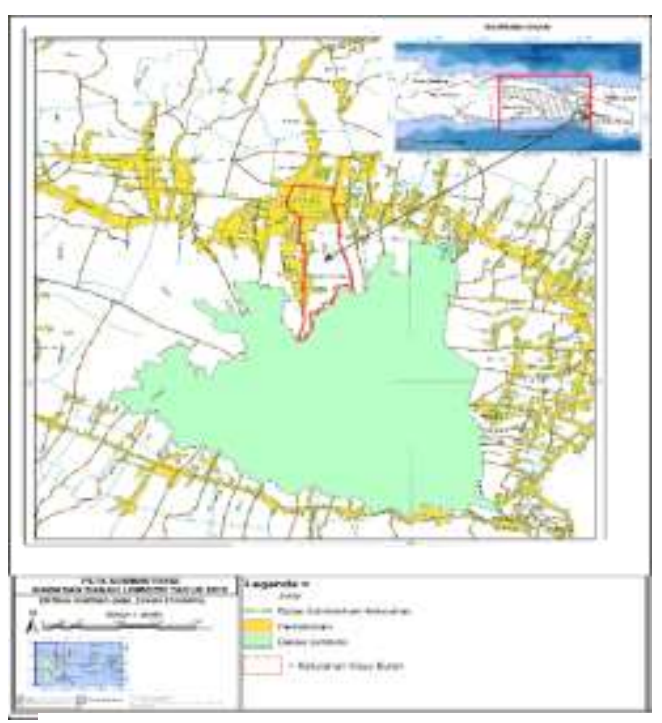

Fig. 1. Location of Study (Author, 2019)

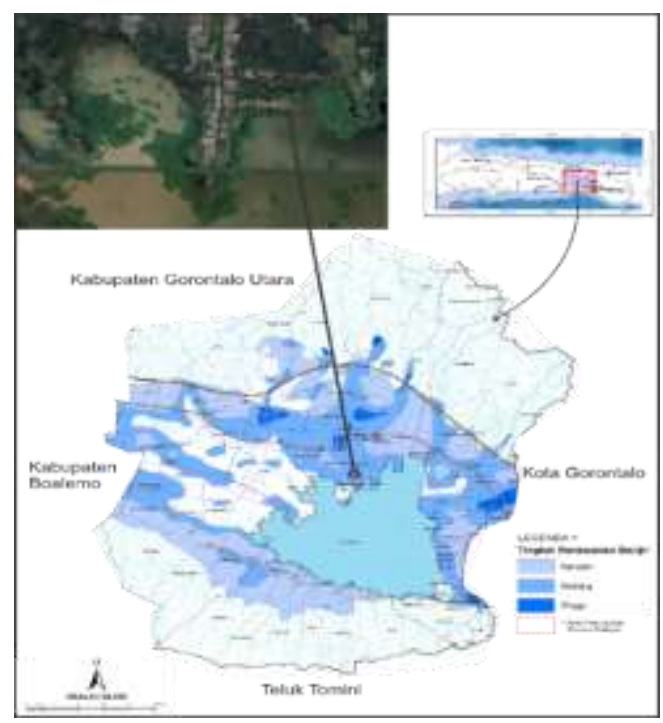

Fig. 2, Fishermen Special Housing Location on Limboto Lake (Author, 2019)

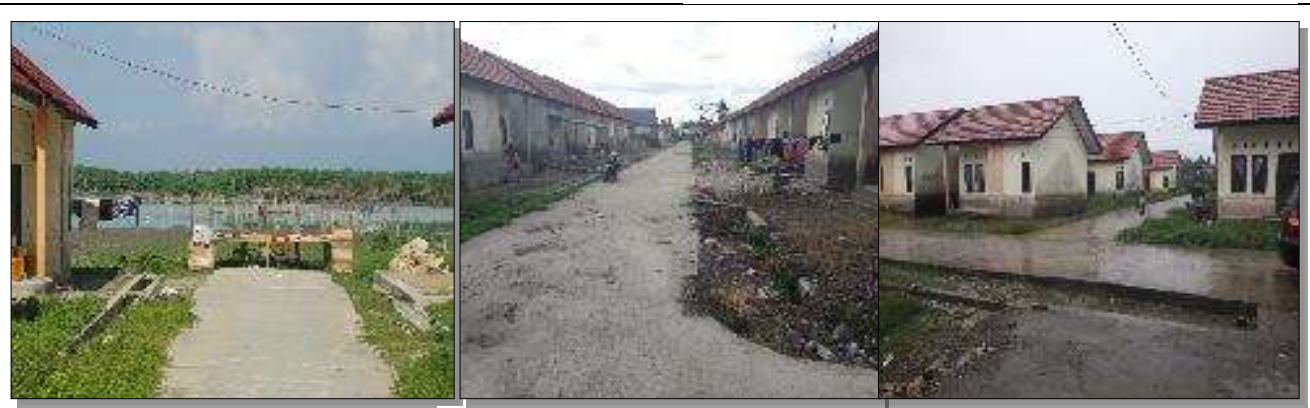

Fig. A. Special housing conditions in Kayubulan directly adjacent to the lake Limboto.
Fig. B. Special housing conditions Limboto Lake on fishermen area of Kayubulan less maintained.
Fig. C. Special home at Limboto because it is not occupied by their owners because often floods. 


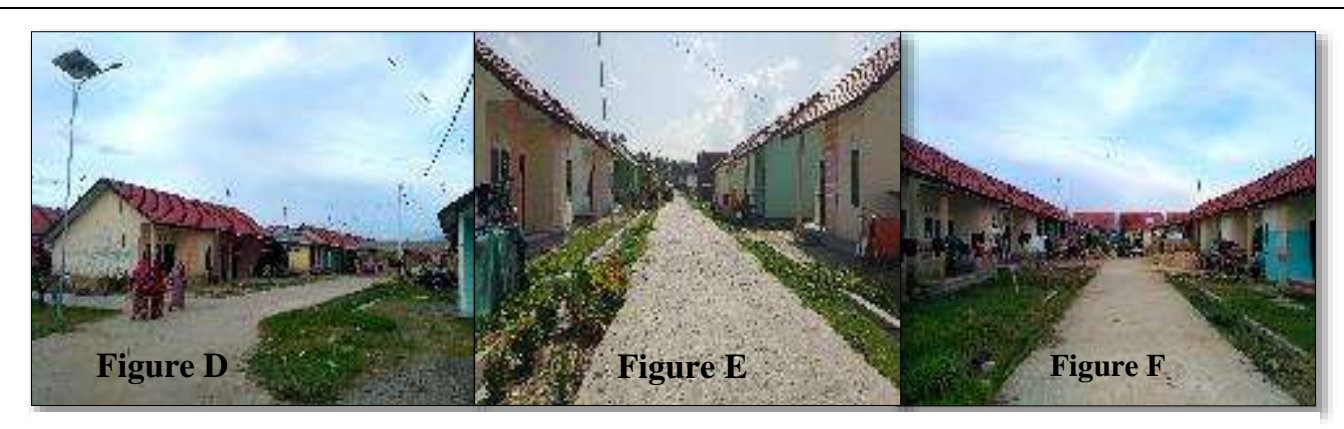

Fig. D, E, F. Special housing conditions in fisherman area which at the time did not flood.

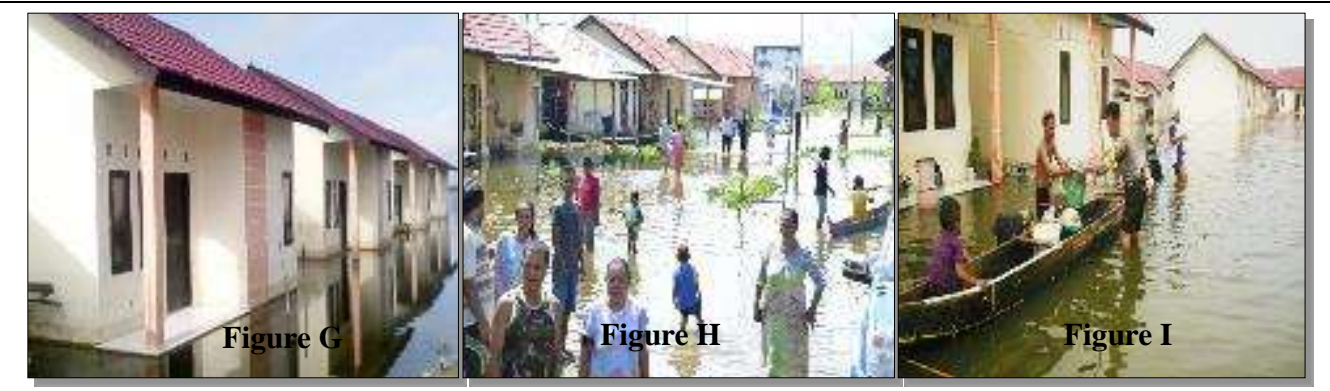

Fig. D, E, F. Special housing conditions which floods at the time.

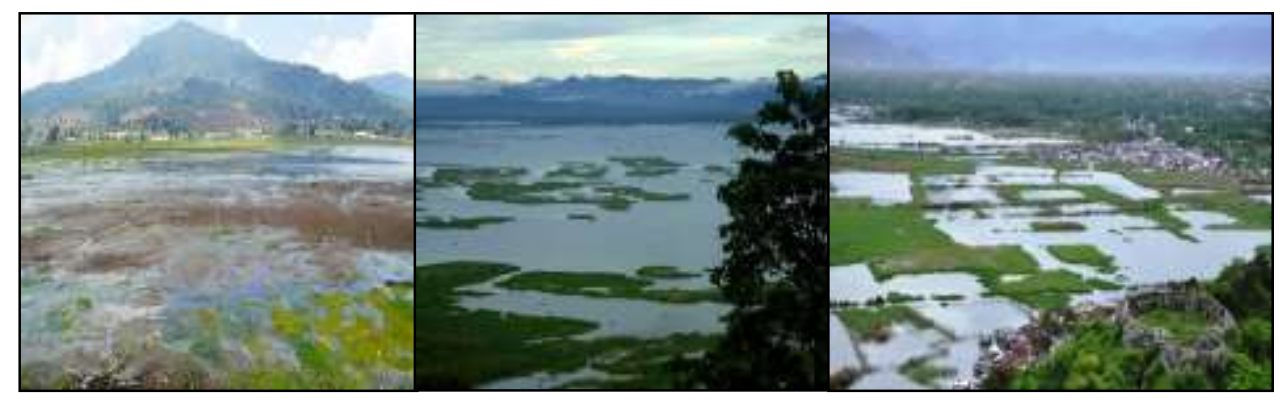

Fig. 3. Limboto already silting the lake and surrounded by residentials. 


\section{Data and Methods}

\subsection{Data}

This study required data consisted of primary data and secondary data. Primary data obtained by field observation, interviews and questionnaires. The questionnaire was only distributed to 13 respondents who previously determined that the experts consisting of academics universities, government agencies, private sector and fishing communities. Secondary data was obtained from literature study, data and information from government agencies. Review of the literature to formulate criteria and sub-criteria used in determined the direction of spatial use for sustainable residential. Data and information from the agency and planning documents to obtain data on the general idea of the location of good research potentials, limitations and problems of the research area.The criteria and sub criteria formulated serve as the basis to obtain qualitative and quantitative data.

Qualitative data used to assessment of the respective interests comparison criteria, subcriteria and alternative spatial useshown in the questionnaires filled out by respondents / experts selected by interview, while quantitative data such as the weight value of each criteria, sub-criteria and alternatives.

\subsection{Research Methods}

This study uses combination method which is a qualitative method with a quantitative data approach (Creswell, 2015). The quantitative data approach itself focuses on the phenomena that occur and also certain characteristics which called variables. And then quantitative approach uses certain variables based on scientific theories / rules that are empirical, objective, rational and systematic. In this study, a quantitative method used to select the decision to perform an irregular structuring issues for later prioritization based on perception and intuition of experts. The analytical approach of this research is descriptive qualitative.Descriptive qualitative research is research that attempt to describe a phenomenon, events, or events that occur when now (Noor, 2012), this approach based on field observation to explore the potential and limitations of spatial use in Kayubulan village.

Sampling technique using purposive sampling to determine respondents which the technique by sampling considerations. This technique has certain considerations in sampling for specific purpose (Riduwan, 2013). Data from respondent questionnaires determine to the criteria, sub-criteria and alternative were analyzed by Analytic Hierarchy Process (AHP) method. Analytic Hierarchy Process (AHP) is a method that helps solve complex problems by structuring a hierarchy of criteria, stakeholders, results and by attracting a variety of considerations in order to develop a weight or priority. This method aims for determine weighting of the criteria, sub-criteria and alternativespriority landing space utilization for residential selected based on the perception of respondents. (Saaty, 1991).

Early stage on the Analytic Hierarchy Process (AHP) is to develop a hierarchy began of objectives (level 1), criteria (level 2), sub-criteria (level 3) and alternative (level 4). In this study, there are five (5) criteria used are: (1) environment and disaster; (2) economy; (3) social and cultural rights; (4) accessibility and (5) availability of facilities and infrastructure, while the sub-criteria used, there are 18 sub-criteria. While the utilization of alternative scenarios for residential area in this study used two (2) categories:The first alternative to maintain the existing condition because the research area is deemed unfeasible to be developed into a residential area and the second alternative is spatial use with limited conditional development 
considering the potential and limitations of the research area. For more details, the structure of the Analytic Hierarchy Process (AHP) this research can be seen in Figure 3. The second step is to create a pairwise comparison matrix of criteria, sub-criteria and alternative utilization of space. This matrix is used as a questionnaire to be filled out by the respondent to provide an assessment of each of the criteria, sub-criteria and alternatives. The third stage is assessment of significance criteria, sub-criteria and alternatives. Assessment of importance level given by respondentsis based on the rating ranking scale with a value of 1-9 (Saaty, 1991) as attached in table 1. The fourth stage to determine the weight of each criteria, sub-criteria and alternatives.In this study, the process of for calculates importance level (weight) of each criteria, sub criteria and alternatives, assist by Analytic Hierarchy Process (AHP) calculator.

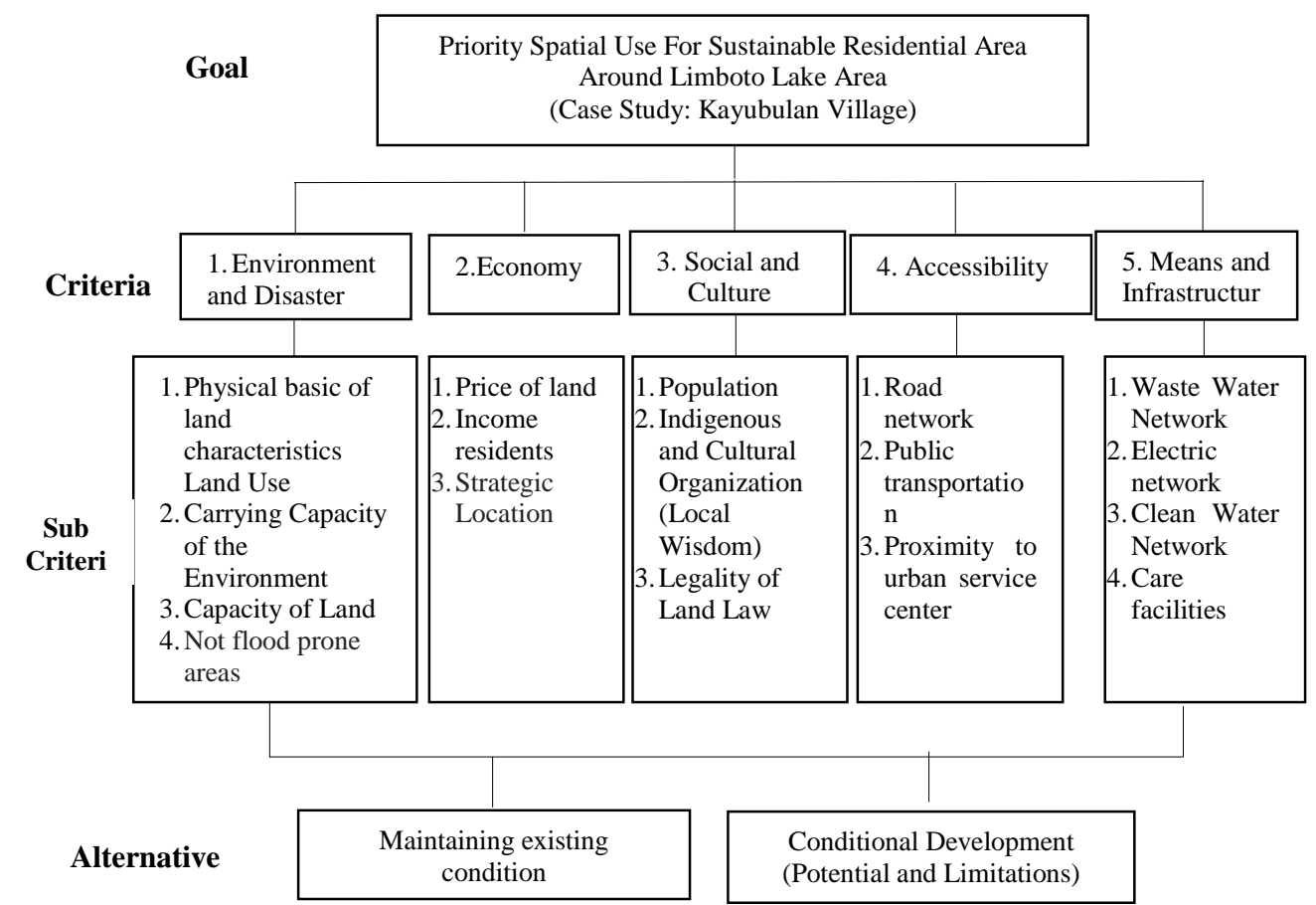

Fig. 4. AHP Structure.

To determine assessment given by respondents are consistent or not, then do consistency ratio value calculation called "consistency ratio" (CR). Consistency Ratio (CR) is consistency level of the answers of respondents gave judgment against the criteria, sub criteria and alternatives proposed in the questionnaire. To declare that such values are consistent, then the calculation results Consistency Ratio (CR) should be $\leq 0.1$. If the value Consistency Ratio $(\mathrm{CR})$ is getting close to zero then the value is expressed more consistent, but if the value Consistency Ratio (CR) of more than $0.1(\geq 0.1)$ then needs to be repeated filling out the questionnaire because it was considered the respondent is inconsistent in its assessment. In table 1 describe Saaty scale rankings which describes at table below. 
Table 1. Interest Rate Saaty scale rankings

\begin{tabular}{cl}
\hline $\begin{array}{c}\text { Importance } \\
1\end{array}$ & \multicolumn{1}{c}{$\begin{array}{c}\text { Definition } \\
\text { Equally Important }\end{array}$} \\
\hline 3 & A little more important \\
5 & Obviously more important \\
7 & Very obviously more important \\
9 & Certainly / absolutely more important (to the extreme interest) \\
$2,4,6,8$ & If you hesitate between two adjacent tilapia \\
$1(1-9)$ & The reciprocal value of the interest rate of 1-9 scale \\
\hline
\end{tabular}

\section{Results and Discussion}

\subsection{Criteria and Sub Criteria Priority Spatial Use for Residential}

Based on calculations using Analytic Hierarchy Process (AHP) obtained that main priorities selected criteria are environment and disaster criteria with the calculation process as much as 5 (five) iteration. After five (5) times the values obtained iterations Consistency Ratio (CR) of $0.9 \%$ or 0,009 . This suggests that the assessment that respondents were consistent, because the value Consistency Ratio (CR) obtained by $0.9 \%$ or 0,009 already $\leq 0.1$. From AHP calculations, found that the top priority criteria in this study is the environment and disaster criterion with a weighting of $48 \%$. When sorted by the amount of weighted criteria, then the order of highest to lowest ranking criteria are: environment and disaster criteria (48\%); accessibility criteria (16.2\%); economic criteria $(15.6 \%)$; criteria for facilities and infrastructure $(10.6 \%)$ and the lowest weighted criteria are social and cultural criteria $(9.6 \%)$.

Table 2. Priority Criteria Weight Calculation Results

\begin{tabular}{clccccc}
\hline No. & \multicolumn{1}{c}{ Criteria } & Weight & Ranking & $\boldsymbol{\lambda} \max$ & iteration & CR \\
\hline 1. & Environment and Disaster & $\mathbf{4 8 \%}$ & $\mathbf{1}$ & & & \\
2 & Accessibility & $16,2 \%$ & 2 & & & \\
3. & Economy & $15.6 \%$ & 3 & 5.039 & 5 & $0.9 \%$ \\
4. & Facilities and infrastructure & $10.6 \%$ & 4 & & & \\
5. & Socio-cultural & $9.6 \%$ & 5 & & & \\
\hline
\end{tabular}

Source: Authors analysis, 2019.

After calculates the weight criteria, next step is to calculate the weight of sub-criteria for each criteria. The process of weight calculation of each sub criteria which each criteria equal to the weight calculation criteria, The final stage for calculating the weights of criteria and sub-criteria in the Analytic Hierarchy Process (AHP) that calculate the final weight of each sub-criterion (18 sub-criteria) by multiplying the weight of each sub-criteria and also weighting of criteria ( 5 criteria). The final weight used in determining the priority sub-criteria that most influence on spatial usefor residentials in Wood Village Neighborhood Moon Lake Limboto. Based on the results of the final weight calculation, then the final weights obtained sub-criteria as shown in Table 4. 
Table 4. Final Result Criteria Weighting Sub Priority

\begin{tabular}{|c|c|c|c|}
\hline \multirow{2}{*}{ No. } & \multicolumn{3}{|c|}{ 1. Environment and Disaster Criteria (Weighting 48\%) } \\
\hline & Criteria and Sub-Criteria & Weight & End weights \\
\hline 1. & Land Characteristics & $8: 40 \%$ & $4: 02 \%$ \\
\hline 2. & Land Use & $18: 20 \%$ & $8.70 \%$ \\
\hline 3. & Land capacity & $25.60 \%$ & $12: 24 \%$ \\
\hline 4. & The environment capacity & $12: 10 \%$ & $5.78 \%$ \\
\hline \multirow[t]{3}{*}{5.} & Not a disaster area & $35.60 \%$ & $17: 02 \%$ \\
\hline & \multicolumn{3}{|c|}{ 2. Economic criteria (Weighting $15.7 \%$ ) } \\
\hline & Sub Criteria & Weight & End weights \\
\hline 1. & Price of land & $29.00 \%$ & $4: 55 \%$ \\
\hline 2. & Revenue community & $44.00 \%$ & $6.91 \%$ \\
\hline \multirow[t]{3}{*}{3.} & Strategic location & $27.00 \%$ & $4: 24 \%$ \\
\hline & \multicolumn{3}{|c|}{ 3. Social and cultural criteria (Weighting 9.6\%) } \\
\hline & Sub Criteria & Weight & End weights \\
\hline 1. & Population & $24.20 \%$ & $2: 32 \%$ \\
\hline 2. & Customs and culture & $30.90 \%$ & $2.97 \%$ \\
\hline \multirow[t]{3}{*}{3.} & Legality of land law & $44.80 \%$ & $4: 30 \%$ \\
\hline & \multicolumn{3}{|c|}{ 4. Accessibility criteria (Weighting $16.3 \%$ ) } \\
\hline & Sub Criteria & Weight & End weights \\
\hline 1. & Road network & $60.60 \%$ & $9.88 \%$ \\
\hline 2. & Public transport & $24.10 \%$ & $3.93 \%$ \\
\hline \multirow[t]{3}{*}{3.} & Proximity to urban centers & $15: 30 \%$ & $2: 49 \%$ \\
\hline & \multicolumn{3}{|c|}{ 5. Facilities and infrastructure criteria (Weighting $10.7 \%$ ) } \\
\hline & Sub Criteria & Weight & End weights \\
\hline 1. & Sewerage & $8.90 \%$ & $0.95 \%$ \\
\hline 2. & Electric network & $31.70 \%$ & $3: 39 \%$ \\
\hline 3. & Water network & $45.10 \%$ & $14: 30 \%$ \\
\hline 4. & Public facilities & $14: 20 \%$ & $4: 50 \%$ \\
\hline
\end{tabular}

Table 5. Spatial Use Sub Priority Criteria To Residential

\begin{tabular}{|c|l|c|c|}
\hline No. & \multicolumn{1}{|c|}{ Priority Sub Criteria } & Final Weights (\%) & Ranking \\
\hline 1. & Not a flood prone area & $17: 02 \%$ & 1 \\
\hline 2. & Water network & $14: 30 \%$ & 2 \\
\hline 3. & Land capacity & $12: 24 \%$ & 3 \\
\hline 4. & Road network & $9.88 \%$ & 4 \\
\hline 5. & Land use & $8.70 \%$ & 5 \\
\hline 6. & Revenue community & $6.91 \%$ & 6 \\
\hline 7. & The environment capacity & $5.78 \%$ & 7 \\
\hline 8. & Land price & $4: 55 \%$ & 8 \\
\hline 9. & Public facilities & $4: 50 \%$ & 9 \\
\hline 10. & Legality of land law & $4: 30 \%$ & 10 \\
\hline 11. & Strategic location & $4: 24 \%$ & 11 \\
\hline 12. & Land characteristics & $4: 02 \%$ & 12 \\
\hline
\end{tabular}




\begin{tabular}{|c|l|c|c|}
\hline No. & \multicolumn{1}{|c|}{ Priority Sub Criteria } & Final Weights (\%) & Ranking \\
\hline 13. & Public transport & $3.93 \%$ & 13 \\
\hline 14. & Electric network & $3: 39 \%$ & 14 \\
\hline 15. & Customs and culture & $2.97 \%$ & 15 \\
\hline 16. & Proximity to urban centers & $2: 49 \%$ & 16 \\
\hline 17. & Population & $2: 32 \%$ & 17 \\
\hline 18. & Sewerage & $0.95 \%$ & 18 \\
\hline
\end{tabular}

Based on the results of final calculation on weighted sub-criteria of priority as shown in Table 5, shows that the sub-criteria chosen priorities is a regional sub-criteria not flood prone area with weighting on 17:02\%. These results indicate that to determine direction of spatial use for residential at Kayubulan is not flood prone area. The results of selection of these respondents equally with the Indonesian Government Regulation number 26 Year 2008 on Spatial Planning at Article 71 that the determination of residential area, there are three (3) important criteria that must be considered that should (1) be outside area defined as a disasterprone areas, (2) have access to a community center outside the area, and (3) has a complete infrastructure, facilities, and utilities. In line with the National Spatial Plan, Muta'ali Lutfi (2013) also believes that characteristics of the location and suitability of land for determining allowment area of residentials must meet several criteria including: flat to rolling topography (slope 0-25\%); available water resources; is not in disaster-prone areas (landslides, floods, erosion, abrasion, tsunami); good to moderate drainage; not on the river border area / beach / reservoir / lake / springs / irrigation canal / railway and flight safe area; not on protected areas; not located in the farm area / buffer; avoid technical irrigated rice.

However, some of the existing residential area in Kayubulan village are located in protected area of Limboto Lake. This area which in a lake body that has been turned into land. It is important to consider environmental and disaster aspects because environment and disaster are two aspects that interconnected each other. Environmental damage can increase natural disasters risk, which one is floods and natural damage levels also a determinant of the high and low risks of floods that occur. Therefore, it is important to prioritize the environment and disaster in spatial use at Kayubulan village because in this area borders directly with Limboto Lake and often floods during overflow water of Limboto Lake. In connection with the explanation, it is very appropriate if respondent makes the environment and disaster a priority criteria, which that the importance of spatial use for residentials because the development of residential areas in inappropriate areas will endanger the surrounding environment or human soul as a resident of the residential area.

In planning of residential development on Kayubulan village, it is important to consider environmental aspects especially preservation because the quality of the residential environment will affect the comfort of the people living at that area. According to Doxiadis (1971) regarding residentials, there are 5 (five) important principles that are considered to create human relations with the residential environment that are interconnected with each other, namely: (1) Nature, (2) Network ; (3). Buildings; (4) Society; and (5) Man. It is important to consider environmental aspects related to the function of Limboto Lake. Because as a flood controller, it can provide comfort and also as an economic resource for the surrounding community who work as fishermen. As stated by Connell \& Miller (in Adrianto et al., 2009) that the existence of a lake ecosystem provides a beneficial function for human life such as providers of comfort, culture, education, environmental services, social services, spiritual services, community resilience, economic, social- ecology and recreation. 


\subsection{Priority Manager Sustainable Land Use For Conditional Residentials}

Based on calculation of priority level at importance (weight) using the AHP method that considering respondent perceptions, the results obtained that first alternative by maintaining existing conditions weights $27.17 \%$ and the second alternative by conditionally limited sustainability residential weights of $72.83 \%$. This shows that respondents prefer the second alternative as the first priority of spatial use for sustainable residential in Kayubulan village because the second alternative has a greater importance (weight) than the first alternative. For more details about the results of AHP calculation Alternative use of space for residentials can be seen in table 6 .

Table 6. Alternative Weight of Spatial Use for Sustainable Residentials in Kayubulan Village

\begin{tabular}{|l|c|c|}
\hline \multicolumn{1}{|c|}{ Sub Criteria } & $\begin{array}{c}\text { Alternative One Maintaining } \\
\text { Existing Conditions }\end{array}$ & $\begin{array}{c}\text { Second Alternative } \\
\text { Limited Conditional Use }\end{array}$ \\
\hline Not a flood prone area & 59.40 & 40.60 \\
\hline Water network & 18.10 & 81.90 \\
\hline Land capacity & 35.20 & 64.80 \\
\hline Road network & 40.60 & 59.40 \\
\hline Land use & 11.50 & 88.50 \\
\hline Revenue community & 42.80 & 57.20 \\
\hline The environment capacity & 25.50 & 74.50 \\
\hline Land price & 22.9 & 77.1 \\
\hline Public facilities & 23.1 & 76.9 \\
\hline Legality of land law & 58.20 & 41.80 \\
\hline Strategic location & 18.3 & 81.7 \\
\hline Land characteristics & 17.8 & 82.2 \\
\hline Public transport & 17.8 & 82.2 \\
\hline Electric network & 20.60 & 79.40 \\
\hline Customs and culture & 18.60 & 81.40 \\
\hline Proximity to urban centers & 20.20 & 79.80 \\
\hline Population & 20.40 & 79.60 \\
\hline Sewerage & 18.10 & 81.90 \\
\hline Average & $\mathbf{2 7 . 1 7}$ & $\mathbf{7 2 . 8 3}$ \\
\hline Total & & \\
\hline
\end{tabular}

Spatial use for conditionally sustainable residentials on a limited basis means that the effort is to build residentials in Kayubulan village by considering the potential and limitations. And also following the limits set out in policies, regulations and guidelines both in terms of spatial aspects, disaster aspects and environmental aspects so that does not cause adverse impacts on the surrounding environment, especially for Limboto Lake and the existence of existing residential areas.

The potential of the Kayubulan village which developes into residential areas have access to high antaralain; the center of trade/economic and Gorontalo Regency administration so that it has a complete infrastructure and facilities; sloped ramps and flat $0-15 \%$ that deserve to be as developed regions; as well as having a high accessibility so easy to reach. It is also 
within the Strategic Area Plan of Limboto Lake, Kayubulan village designated as an urban residential area of district of Limboto.

In addition to having potential develop as a residential area, Kayubulan village also have limitations for residentials area. Limitation to be developed as residential areas can not be separated from Kayubulan village position set out in the Spatial Plan of Gorontalo Regency Year 2012-2032 and Strategic Area Plan of Limboto Lake which in Year 2017, Limboto Lake as strategic areas; coastal areas; border region and around the lake; flood disaster areas and administrative boundaries of the Kayubulan village directly adjacent to Limboto Lake. Position in the spatial plan should be one of the aspects considered in the spatial usefor residentials in the Kayubulan village, which for coastal areas (waterfront).

Based on the explanation limitations of Kayubulan village and outcome criteria and sub criteria chosen priorities results of the respondents, it can be concluded that the direction of spatial use for residential that conditional use and consider the spatial, environment and disaster aspects. Environmental and disaster are the two aspects that related each other. Environmental degradation can increase the risk of natural disasters, one that floods, and the degree of environmental damage also a determinant of the level of risk of floods occurring.

Limitations of Kayubulan village closely related to the presence of Limboto Lake that one of natural resources of Gorontalo Province which serves as a conservation area, the protected area, and flood control for Gorontalo Province, especially for Gorontalo Regency and Gorontalo capital city. So that, necessary restriction of spatial use for residentials in Kayubulan village. If not directed and constrained the residentials will continue to grow which will directly improve human activity to exploit the natural resources of Lake Limboto excessive land use changes around the lake are uncontrollable, which will result in decreased capacity of the environment and thus potentially doubling the probability of floods inresearch area. According to Kodotie (2013) that one impacts of human activities that exploit natural resources excessive is an increase disasters, especially floods in terms of both quantity and quality. It can be concluded that the control and limitation of residentials in the Kayubulan village in an effort to reduce the potential for flooding in the study area and the surrounding area.

Planning for develop residential area in Kayubulan village also be adapted and aligned with the plans and objectives of the existing spatial arrangement. Spatial plan relating to the existence study is the Spatial Plan of Gorontalo Regency number 4 year 2013, which aims at realizing Gorontalo Regency support food security by optimized management of natural resources and preserving the environment as well as the Spatial Plan of Strategic Provincial Region Limboto Lake Number 9 Year 2017 aims at realizing Limboto Lake Region as a center for the integration of development of a sustainable environment in the system of spatial planning and optimal matching by promoting conservation and meet the carrying capacity and environmental capacity.

Environmental aspects need to considered in spatial use for sustainable residentials in Kayubulan village including environmental sustainability and harmony; balance of the use of existing resources; carrying capacity of the environment which must begin at the planning, management and development stages. This meant that the direction of development of spatial use to grow harmoniously according to sustainable development principles both economically, environmentally, socially and culturally. As explained by Anih (2012) that the planning of residentials should be based on ecological approaches to ensure sustainable.

Another aspect to consider for residentials which must be harmonized with the regional spatial planning that about zoning rules for lake borders. In Spatial Plan of Strategic Provincial Region Limboto Lake, the area borders the lake that is 50 meters from the edge of the water 
body lake plus areas for the construction of canals and road access to the lake with a distance of 40 meters from the boundary demarcation, as well as 100 meters from the edge lake water bodies that do not bertanggul. In Spatial Plan of Strategic Provincial Region Limboto Lake (Article 51) explained that the directions of zoning regulations for areas prone to flooding, permitted activities among others: the construction of flood control structures, reforestation activities, manufacture of recharge wells,

The development of spatial use for a sustainable residential must adapt to the environment of Limboto Lake, and considering the physical condition of area. To realize a sustainable residential must be accompanied by prevention and preparedness planning efforts 'mitigation' to reduce flood impact to people who are already living in the location and to anticipate residentials development that would happen. Prevention and preparedness 'mitigation' flood performed must be adapted to the environmental aspects that can keep Limboto Lake neighborhood.

For the spatial use for residential sustained by considering environmental aspects, flood mitigation and the position of the Kayubulan village as residential area of coastal lakes, then the concept of residential recommended must be concept of residential green waterfront residential that takes into account the environmental, economic and social with the concept of building a house wet flood proofing (Source: Kiran Curtis, Architect KCA), which houses more than one floor (houses on stilts). The house construction is done more towards the physical, technical civilian like building a house with the house building form the stage / floating and materials made from materials that are environmentally friendly.

\section{Conclusion}

To determine the priority of spatial use for sustainable residentials in this study used 5 criteria and 18 sub-criteriaassist by Analytic Hierarchy Process (AHP) method. This method shows that the priority of spatial use for sustainable residentials is conditionally limited to the level of importance (weight) at $72.83 \%$. While the selected criteria as priority in spatial use for sustainable residentials in Kayubulan village are environmental and disaster aspects with the acquisition of an interest level (weight) of $48 \%$ also the priority sub-criteria being that the residential area is not a flood prone area with a weight of $17.02 \%$.

Spatial use for sustainable residentials carried out by considering spatial aspects, environmental aspectsand disaster aspects which refer to the provisions and provisions stipulated in the Gorontalo Regency Spatial Plan. Guidelines for spatial use control in flood prone areas, guidelines for preparing Detail Spatial Plan and Zoning Regulations of Regency/ City, spatial planning law and other related technical guidelines regarding requirements indeveloping residential areas in coastal areas. Requirements and conditions that must be met include the limitation of spatial intensity (KDB, KLB, KDH, clearance and height of buildings), limiting the amount of space used for residentials by calculating the capacity and carrying capacity of the environment, and the stipulated lake borderregulations (50 meters), the provision of green open space to maintain the balance of the Limboto Lake ecosystem, regulations for the form of 'flood proofing' houses with environmentally friendly structures and types of building materials. 


\subsection{Acknowledgments}

Praise the presence of God Almighty who has bestowed His grace and wisdom, so that the author can complete this article. This article is part of a thesis entitled "Priority of Spatial Use for Sustainable Residentials in Kayubulan village Around Lake Limboto Area". On this occasion the author would like to thank Dr. Ir. Ragil Haryanto, MSP as the second supervisor and writer who has provided input and support, so that this study can be completed and presented well. Do not forget the authors also thank the Ministry of Public Works and Public Housing of Indonesia for funding this study.

\section{References}

Adrianto, L., Arsyad Al Amin, M., Solihin, A., Hartoto, D. I., \& Satria, A. 2009. Local knowledge and fisheries management. Bogor: Center for Coastal and Marine Resources Studies, Bogor Agricultural Instititute.

Connell, DW and Miller GJ. 1995. Chemistry and Ecotoxicology of Pollution. Jakarta: UI Press.

Creswell, JW, \& Creswell, JD, 2017. Research design: Qualitative, quantitative, and mixed methods approaches. Sage publications.

Daldjoeni, N. 1996. Urban and Rural Geography. Alumni, Bandung.

Kirmanto, Djoko, 2002, the Housing and Residential Development of environmental Insight Strategic Urban Flood Prevention, Care Seminar delivered in the Flood "FOREST" Jakarta March 25, 2002

Kodoatie, Robert J. 2013. The State Flood Management Engineering. Yogyakarta: Andi.

Muta'ali, L. 2013. Spatial planning regions and cities: a review of normative-technical. Publisher Agency, Faculty of Geography, University of Gadjah Mada.

Mitchell, B., B. Setiawan and DH Rahmi, 2003, Resource and Environmental Management. Yogyakarta: Gadjah Mada University Press

GOI, 2007. Law No. 26 Year 2007 on Spatial Planning. Jakarta: GOI

Gorontalo Regency Government, 2012. District Spatial Plan (RTRW) Gorontalo Regency 2012-2032.

Lusht Kenneth M, 1997. Real Estate Valuation Priciples and Application, Chicago:Irwin.

Riduwan. 2004. Methods and Techniques Thesis Preparation. Publisher Alfabeta: Bandung

Saaty, TL 1991. Response to Holder's Comments On The Analytic Hierarchy Process. Journal of the Operational Research Society, vol. 42 (10), pp. 909-914.

Sadana, Agus S. 2014. Planning Residential Region. Yogyakarta: Graha Science.

Sulistiono, Bambang. High River Flood Inundation Study in Urban Code, Yogyakarta (Flood Analysis for Code River, DIY), Journal of Scientific Journal of Engineering inundated No. 213 (1), Semarang: Diponegoro University; 2006.

Widodo, B., Prinz, D.: A Case of Farm Land Conversion: Land Under Threat, International sured Seminar, Land and Water Resources Management, DAAD, University of Karlsruhe, University of Oldenberg, Chiang Mai (2004) 